\section{Correlation between Amount of Aggregates Formed on Freezing of Immunoglobulin $G$ and Protein Concentration}

ULLA-BRITT HANSSON

Department of Clinical Chemistry, University of Lund, Malmö General Hospital, S.21401 Malmö, Sweden

Tn general, proteins are more stable in concentrated than in dilute solution, ${ }^{1}$ but in vivo aggregated myeloma protein of type $\mathrm{IgG}{ }^{2}$ dissociates when the globulin is diluted. Purified fractions of immuno. globulin $\mathrm{G}(\mathrm{IgG})$ form large amounts of aggregates when frozen and thawed. ${ }^{3}$ The presence of immunoglobulin aggre. gates is believed to be one cause of the side effects of intravenous administration of gammaglobulin." Pure IgG preparations are often stored at $-20^{\circ} \mathrm{C}$ until used. In the range of $0.2-1.4 \mathrm{~g} / 100 \mathrm{ml}$ the effect of freezing on the degree of aggregation does not seem to vary with the protein concentration. ${ }^{3}$ The purpose of this study was to ascertain whether a correlation exists between immunoglobulin concentration in the range of $1-10 \mathrm{~g} / 100 \mathrm{ml}$ and the amount of aggregate formed on freezing of the sample.

It is easier to prepare non-aggregated $\mathrm{IgG}$ from an individual serum than from a serum pool (unpublished observation). Such globulin preparations from normal sera as do not contain the anodal fraction of the gammaglobulin on agarose gel electrophores at $\mathrm{pH} 8.6$ seem to aggregate less than do sera containing the entire population of molecules. ${ }^{5}$ These findings were taken into account in the selection of the material and preparation techniques.

The starting material consisted of $150 \mathrm{ml}$ serum from one normal person and $150 \mathrm{ml}$ from a pool of sera from several hundred persons, including both healthy subjects and patients with various diseases. Both samples were precipitated with ammonium sulphate $(1.84 \mathrm{M})$ in the way described previously. ${ }^{6}$ The material from then normal serum was purified on DEAE Sephadex A 50 according to Högman and Killander ${ }^{7}$ and afterwards dialysed against $0.05 \mathrm{M}$ phosphate buffer
$\mathrm{pH} \quad 7.0, \quad 0.5 \mathrm{M}$ in respect of $\mathrm{NaCl}$. The material from the pool was purified on DEAE-cellulose and Sephadex G 200 in the way described previously ${ }^{6}$ and was dissolved in the same buffer. Electrophoresis on agarose gel at $\mathrm{pH} 8.6$ of the IgG fractions from the DEAE-Sephadex A 50 column showed that the fractions were made up almost entirely of the cathodal fraction of $\operatorname{IgG}$, whereas the IgG fractions from the DEAE-cellulose and Sephadex G 200 contained IgG molecules distributed more equally in the entire gammazone.

Each purified globulin fraction was concentrated to $11 \mathrm{~g} / 100 \mathrm{ml}$. The protein concentration was estimated as described earlier. ${ }^{3}$ From the concentrated solution a dilution series with $0.05 \mathrm{M}$ phosphate buffer $\mathrm{pH} 7.0$, $0.5 \mathrm{M}$ in respect of $\mathrm{NaCl}$, in the range of 0.5 to $11 \mathrm{~g} / 100 \mathrm{ml}$ was prepared. Approximately equal volumes of these samples were frozen and thawed 10 times and afterwards stored at $-20^{\circ} \mathrm{C}$ for 5 months. Immediately after they had been thawed and after those in the range $2-11 \mathrm{~g} / 100 \mathrm{ml}$ had been diluted to a concentration of $1 \mathrm{~g} / 100 \mathrm{ml}$ they were run in a Spinco Analytical Ultracentrifuge with Schlieren Optics. The distribution between $7 \mathrm{~S}$ molecules and aggregates was estimated. 3

The result of this analysis is shown in Fig. 1. In the IgG from the normal serum $14 \%$ of the molecules had formed aggregates when the gammaglobulin

$\%$

AGGREGATES

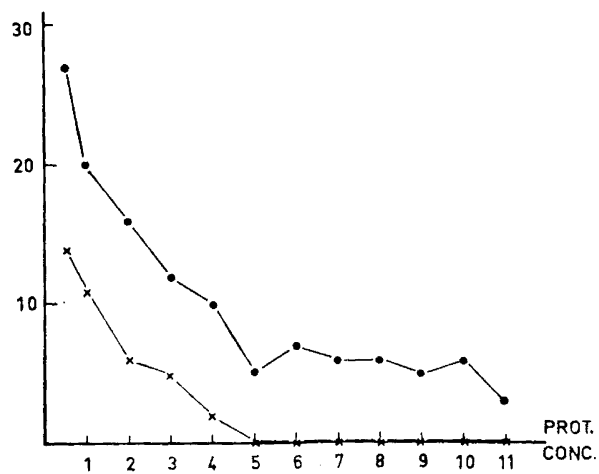

Fig. 1. Per cent of aggregates formed in frozen IgG solutions containing increasing amounts of globulin. $\times$ IgG from one normal serum; IgG from a pool of sera. Protein conc. in $\mathrm{g} / 100 \mathrm{ml}$.

Acta Chem. Scand. 23 (1969) No. 5 
had been frozen at a concentration of $0.5 \mathrm{~g} / 100 \mathrm{ml}$. With increasing protein concentration the amount of aggregate formed decreased rapidly so that in the solution containing $5 \mathrm{~g} / 100 \mathrm{ml}$ it was not possible to demonstrate any aggregated globulin. Solutions containing concentrations of protein higher than $5 \mathrm{~g} / 100 \mathrm{ml}$ did not contain aggregated globulin. $27 \%$ of the molecules had formed aggregates in the globulin solution prepared from pooled serum the sample containing $0.5 \mathrm{~g} / 100 \mathrm{ml}$ protein. The amount aggregated was never below $3 \%$ even when the concentration in the solution was $11 \mathrm{~g} / 100 \mathrm{ml}$.

Acknowledgement. This investigation was supported by grants from the Suedish Medical Research Council (Project No. B69-13X581-05A) and Alfred Österlunds fond.

1. Putnam, F. W. The proteins I, Part B (1953) 827.

2. Kochwa, S., Smith, E., Brownell, M. and Wasserman, L. R. Biochemistry 5 (1966) 277.

3. Hansson, U.-B. Acta Chem. Scand. 22 (1968) 483.

4. Barandun, S., Kistler, P., Jeunet, F. and Isliker, H. Vox Sanguinis 7 (1962) 157.

5. Hansson, U.-B. Acta Chem. Scand. 22 (1968) 953.

6. Hansson, U.-B., Laurell, C.-B. and Bachmann, R.' Acta Med. Scand. Suppl. 445 (1966) 89.

7. Högman, C. F. and Killander, J. Acta Pathol. Microbiol. Scand. 55 (1962) 357.

Received June 10, 1969.
Reactivity of Butyllithium in Diethyl Ether Toward Benzonitrile and Methyl Trifluoroacetate TORKIL HOLM

\author{
Department of Organic Chemistry, The \\ Technical University, DK.2800 Lyngby, \\ Denmark
}

Fridence has been accumulating in the last few years for a tetrameric structure of butyllithium in diethyl ether solution. West and Waack ${ }^{1}$ rationalized the observation of a 0.30 order dependence with respect to butyllithium of the addition of butyllithium to 1,1-diphenylethylene as the result of insignificant reactivity of the tetramer but high reactivity of the monomer in the equilibrium:

$\left(\mathrm{C}_{4} \mathrm{H}_{9} \mathrm{Li}\right)_{4} \rightleftharpoons 4 \mathrm{C}_{4} \mathrm{H}_{9} \mathrm{Li} ; \frac{\left[\mathrm{C}_{4} \mathrm{H}_{9} \mathrm{Li}\right]^{4}}{\left[\left(\mathrm{C}_{4} \mathrm{H}_{9} \mathrm{Li}\right)_{4}\right]}=K_{\mathrm{eq}}(\mathrm{I})$

Colligative measurements by West and Waack also indicated a tetrameric structure. Various observations point to the coordination of one molecule of ether for every two equivalents of butyllithium on addition of diethyl ether to a solution of butyllithium in hydrocarbons. ${ }^{2-4}$ This requires the tetramer to be di-solvated and excludes the possibility of a trimer.

Kinetic data obtained in the present investigation may be interpreted according to the theory described and afford further

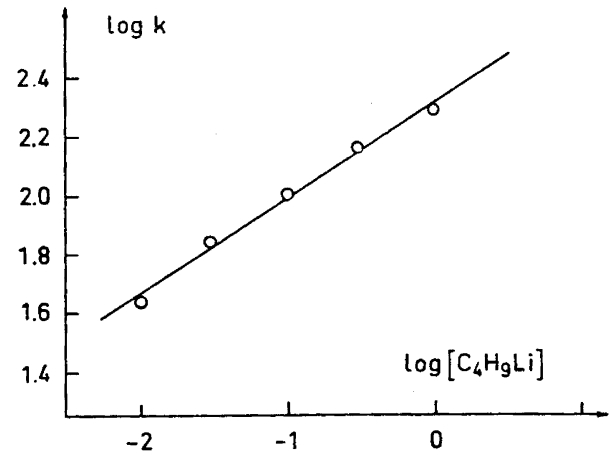

Fig. 1. log pseudo first order rate constant $k$ for the reaction in diethyl ether at $20^{\circ}$ of 0.01 M benzonitrile with butyllithium versus $\log$ $\left[\mathrm{C}_{4} \mathrm{H}_{9} \mathrm{Li}\right]$. 